\title{
VISUOMENĖS SVEIKATOS BIURŲ SPECIALISTŲ DARBUI MOTYVUOJANTYS VEIKSNIAI
}

\author{
Ingrida Jaselskyte் \\ Lietuvos sveikatos mokslų universiteto Visuomenès sveikatos fakulteto \\ Sveikatos tyrimų institutas \\ Betonuotojų g. 4-12B, LT-52371 Kaunas, Lietuva \\ Telefonas $(+370) 60632271$ \\ Elektroninis paštas ingrida.jaselskyte@gmail.com \\ Skirmantė Sauliūnè \\ Lietuvos sveikatos mokslų universiteto Visuomenès sveikatos fakulteto \\ Sveikatos vadybos katedra \\ Šiaurès pr. 57-321, LT-49264 Kaunas, Lietuva \\ Telefonas (+370) 68724996 \\ Elektroninis paštas skirmante.sauliune@lsmuni.lt \\ Pateikta 2014 m. rugpjūčio 25 d., parengta spausdinti 2014 m. rugsèjo 20 d.
}

doi:10.13165/SPV-14-2-7-05

\section{Santrauka}

Tikslas - nustatyti visuomenès sveikatos specialistu, dirbančiu savivaldybiu visuomenès sveikatos biuruose, darbui motyvuojančius veiksnius.

Metodologija - tyrime dalyvavo 55 visuomenés sveikatos specialistai ir įstaigu vadovai, dirbantys visuomenés sveikatos biuruose (VSB), be mokyklu visuomenes sveikatos specialistų. Bendras tyrimo atsako dažnis - 35,2 proc. Statistineje analizèje naudoti šie kriterijai: Chi kvadrato ( $\chi 2)$, Pirsono tiesinès, Spirmeno ranginès koreliacijos koeficientai, Kruskal Wallis testas. Testo klausimu patikimumui nustatyti naudota Cronbacho alfa.

Rezultatai - motyvaciniu veiksniu svarba labiausiai išsiskyre vertinant amžiu ir pareigas. Karjeros galimybès, kaip išorine vertybè, amžiui didèjant tampa mažiau svarbios $(-0,486, p=0,000)$. Nustatytas ryšys tarp amžiaus ir prioriteto darbui su žmonemis, noro igyti darbo patirties, nuolatinès ịtampos dèl didelio krūvio. Pagal pareigas analizuojant motyvacinius veiksnius, labiausiai išsiskyrè veiksniai, susije su veikla. Vadovai, lyginant su specialistais, statistiškai reikšmingai dažniau j̣vardino patiriantys nuolatine įtampa dèl didelio krūvio 
( $p=0,01)$. Vadovai reikšmingai dažniau nei specialistai ịvardino susiduriantys su iššükiais $(p=0,04)$ ir kad norint pasiekti tikslus reikia įdeti daugiau pastangu $(p=0,02)$. Daugiau nei $2 / 3$ respondentu bendraja motyvacija ivvertino kaip „stipria ar labai stipriq“. Tarp bendrosios motyvacijos nustatytas ryšys su amžiumi $(-0,21, p=0,04)$, darbo stažu $(-0,26 ; p=0,01)$, prioritetu darbui su žmonèmis $(0,36$, $p=0,00)$, noru dalyvauti igyvendinant sveikatos politika $(0,45, p=0,00)$, kas ir yra viena iš svarbiausiu veiklos krypčiu VSB.

Tyrimo ribotumas - dèl mažo atsako dažnio tyrimo rezultatai atspindi tik tyrime dalyvavusiujų nuomonę.

Praktinè reikšmé - tyrimo rezultatai naudingi stiprinant visuomenès sveikatos biuruose dirbančiu specialistu motyvacija, savivaldybiu taryboms, bendradarbiaujančioms su visuomenès sveikatos biurais rengiant pareiginius nuostatus, funkcijas, finansavima, Lietuvos Respublikos sveikatos apsaugos ministerijai igyvendinant politinius, ekonominius pokyčius.

Originalumas / vertingumas - savivaldybiu visuomenès sveikatos biuru darbuotojams ir darbdaviams svarbūs darbui motyvuojantys veiksniai nebuvo tirti, nepaisant to, kad šiu specialistu darbas susijęs su visuomenès motyvavimu ir igalinimu gyventi sveikai, stiprinti savo sveikata.

Tyrimo tipas: tyrimo pristatymas.

Reikšminiai žodžiai: visuomenès sveikatos biurai, visuomenès sveikatos specialistai, motyvaciniai veiksniai darbui, motyvacija.

\section{Ivadas}

Motyvacija ir motyvaciniai veiksniai itin aktualūs, kai nèra galimybės darbuotojams suteikti tam tikrų sąlygų, pvz., tokio užmokesčio, kurio nori darbuotojas, užmokestis yra fiksuotas ar per mažas. Kaip ir kiekvienoje organizacijoje, siekiant geriausių rezultatų, stengiamasi sudaryti kuo geresnes sąlygas darbuotojams, naudoti darbuotojams aktualius ir svarbius motyvacinius veiksnius. Motyvaciniai veiksniai visuomet bus individualūs, subjektyvūs. Savivaldybių visuomenės sveikatos biurų darbuotojams ir darbdaviams svarbūs motyvaciniai veiksniai darbui nebuvo tirti, nepaisant to, kad šių specialistų darbas susijęs su visuomenès motyvavimu ir igalinimu gyventi sveikai, stiprinti savo sveikatą, o pirmieji savivaldybių visuomenès sveikatos biurai pradejjo veiklą dar $2006 \mathrm{~m}$.

„Valios barjerai pažymi „nenorą“: žmogaus specifinis elgesys stipriai priklauso nuo jo motyvacijos ir elgesio tikslų. Vykstant kaitos procesams elgesį ir nuostatas galima modifikuoti keičiant vertybines nuostatas arba taikant tinkamas paskatas“ (A. Grybienè, D. Šimbelis, 2005)․․

Grybienè, A.; Šimbelis, D. Pokyčiai organizacijoje: pasipriešinimo pokyčiams valdymas. KTU Panevėžio institutas, 2005, p. 68-71. 
Galiausiai 2008 metais buvo pasiūlytas paprastas motyvacinių veiksnių apibūdinimas viešajame sektoriuje: „motyvai ir veiksmai, nukreipti į visuomenę, yra kilę dèl noro daryti kitiems gera ir formuoti gerovę visuomeneje“ (L. J. Perry, A. Hondeghem, 2008) ${ }^{2}$. Autoriai kelia klausimus: kaip motyvai darbui viešajame sektoriuje sąveikauja su vidiniais asmens motyvais, kaip keičiasi ar nesikeičia darbo motyvai viešajame sektoriuje priklausomai nuo aplinkybių. Tie patys klausimai aktualūs tiriant VSB.

\section{Mokslinès literatūros apžvalga}

Motyvas (lot. motyvum) - veiklos paskata, kuri susidaro dèl subjekto gyvenimo sąlygų ir lemia jo aktyvumo kryptingumą (J. Klimavičiūtė, 2013)³. Tai argumentas, atsakantis ì klausimą, kodèl verta atlikti tam tikrą veiklą (D. Šavareikiené, 2008) ${ }^{4}$. Motyvo vertè gali būti suvokiama kiekvieno asmens skirtingai, priklausomai nuo lūkesčio, orientuoto ị procesą ar galutinị rezultatą, svarbumo. Darbdaviui siekiant igyvendinti organizacijos tikslus, kartais gali tekti naudoti motyvacinius veiksnius, kurie yra svarbūs darbuotojui, taip ịvykstant tam tikriems mainams, kai santykis nusakomas mainais tarp darbdavio ir darbuotojo arba lyderio ir pasekejjų, o už atliktą darbą atitinkamai atsilyginama.

Savivaldybių visuomenès sveikatos biurai - biudžetinès ịstaigos. Pagal Lietuvos Respublikos Konstitucinio Teismo 2004 m. gruodžio 13 d. nutarimą (Nr. 181-6708) „Asmenys, dirbantys institucijose, per kurias vykdomos valstybės funkcijos, sudaro valstybės tarnautojų korpusą. Valstybès tarnyba yra šių asmenų profesinè veikla, susijusi su viešojo intereso garantavimu. Konstitucijoje vartojama sąvoka „valstybės (valstybinè) tarnyba“ savo turiniu yra tapati sąvokai „viešoji tarnyba“. Konstitucijoje yra ịtvirtinta tokia valstybės tarnybos samprata, kuri yra neatskiriamai susijusi su valstybès, kaip visos visuomenès organizacijos, paskirtimi užtikrinti žmogaus teises ir laisves, garantuoti viešąji interesąa. ${ }^{\text {"V VSB }}$ vykdant valstybės funkcijas atstovauja viešajam interesui sveikatos klausimais, stiprinant, stebint sveikatos rodiklius ir atliekant kitas funkcijas, tad ir specialistai gali būti priskiriami valstybės tarnautojams, o ir VSB privalomų pareigybių sąrašą ir joms keliamus kvalifikacinius reikalavimus nustato sveikatos apsaugos ministras.

2 Perry, J. L.; Hondeghem; A. Building Theory and Empirical Evidence about Public Service Motivation. International Public Management Journal. 2008,11(1): 3-12.

3 Klimavičiūte, J. Visuomenès sveikatos biuru veiklos ir veiklos efektyvumo vertinimas: magistro diplominis darbas. Kaunas: Lietuvos sveikatos mokslų universitetas, 2013.

4 Šavareikienè, D. Motyvacija vadybos procese: mokomoji knyga. Šiauliai. Šiaulių universiteto leidykla, 2008.

5 Lietuvos Respublikos Konstitucinio Teismo 2004 m. gruodžio 13 d. nutarimas „Dèl kai kurių teisès aktų, kuriais reguliuojami valstybès tarnybos ir su ja susiję santykiai, atitikties Lietuvos Respublikos Konstitucijai ir ịstatymams“. Valstybès žinios. 2004, Nr. 181-6708. 21. 
VSB gali būti priskiriama viešojo sektoriaus ypatybès, kurias išskiria D. Diskienè (D. Diskienè, 2008) ${ }^{6}$ :

- Atlieka valstybines funkcijas, igyvendina valstybès, o ne savo valią, dirbdami kitų interesų kontekste;

- Darbuotojai užtikrina sąlygas materialinių vertybių gamybai.

- Darbas apmokamas iš valstybés biudžeto.

- Papildomo uždarbio galimybès ribotos.

- Mažas atlyginimas už sudėtingą darbą, apribotas finansinių galimybių. Rizika mažesnè, kadangi veikla minimaliai veikiama vidaus ir išorès veiksnių (ekonominiai, politiniai, socialiniai ir kt.)

- Karjeros ribotumas, kai darbuotojas vertinamas labai gerai, o išlaiko tą pačią kvalifikacijos klasę.

- Fiksuotas darbo laiko grafikas.

Mokslininkai pasiūlè, kad viešojo sektoriaus tarnautojų pagrindinis motyvacinis veiksnys - pasiaukojimas ir jis gali būti susijęs su elgesiu, verte, etika ir darbuotojo požiūriu (S. Kim ir W. Vandenabeele, 2010)7. Pasiaukojimas - tam tikra altruizmo išraiška, kai asmuo kažką praranda tam, kad kažką pakeistų. Tačiau aukoti (laiką, pastangas) nebūtinai gali reikšti pasiaukojimą, jei asmuo nejaučia praradimo ir vis tiek altruistiškai elgiasi. Viešajame sektoriuje dirbančių asmenų motyvacija pradèta nagrinèti dar 1990 metais (J. L. Perry, L. R. Wise, 1990) ${ }^{8}$. Mokslininkai teigè, kad viešajame sektoriuje dirbantys asmenys yra labiau linkę í altruizmą bei stipresni jų vidiniai motyvaciniai veiksniai darbui, labiau būdingas pasiaukojimas (angl. self-sacrifice). Todèl siekiant skatinti darbuotojus įdèti daugiau pastangų, siūloma naudoti daugiau išorinès motyvacijos veiksnių, kai vidiniai motyvaciniai veiksniai yra pakankamai stiprūs.

Viešajame sektoriuje dirbančių asmenų motyvacijai svarbūs veiksniai, susiję su tobulëjimu: išsilavinimu, profesija, su darbo funkcijomis susijusiais gebejjimais. Tam tikrai profesinei veiklai atlikti svarbu turimos žinios, gebejjimai, vertybinès nuostatos, kurios nusakomos kvalifikacija, kai yra tam tikra kompetencijų sistema. Todèl baigus studijas ir gavus diplomą, pripažistama, kad igyta kvalifikacija yra tinkama profesinei veiklai atlikti. VSB specialistų specialiųjų funkcinių užduočių analizė atskleidè, kad stebėsenai, sveikos gyvensenos skatinimui, vaikų ir jaunimo sveikatos stiprinimui vykdyti jie turi šiek tiek daugiau

Diskienè, D. Darbo motyvacija viešajame sektoriuje: iššūkiai ir tikrovè. Viešasis sektorius ir socialine raida. Naujausios tendencijos. 2008, 4(20).

$7 \quad$ Kim, S.; Vandenabeele; W. Measuring Public Service Motivation: Developing an Instrument for International Use. The annual conference of the European Group for Public Administration (Toulouse, France, 8-10 September, 2010). Toulouse.

8 Perry, J. L.; Wise, L. R. The Motivational Bases of Public Service. Public Administration Review. 1990,50(3): 367. 
nei pagrindines žinias ir ịgūdžius (V. Jankauskienè ir kt., 2012) ${ }^{9}$. Galimybè tobulèti ir kelti kvalifikaciją turètų būti kryptingi ir tęstiniai.

Išsilavinimo lygis ir lytis pripažinti geriausiais veiksniais, galinčiais lemti profesinį pasirinkimą dirbti viešajame sektoriuje (L. Bright, 2011) ${ }^{10}$. Išsilavinimo atitiktis reikalavimams siekiant gauti darbą valstybės tarnyboje yra vienas pagrindinių diferenciacinių kriterijų. Igytas išsilavinimas suteikia galimybę rinktis darbą pagal profesiją.

Tiek profesijos, tiek specialybès pasirinkimas gali nulemti ir darbo ar organizacijos pasirinkimą. Todèl motyvacinių veiksnių klausimas aktualus ne tik igyvendinant tam tikras funkcijas, veiklą organizacijoje, bet ir renkantis darbą, suvokiant karjeros galimybes (H. Haase, A. Lautenschläger, 2011) ${ }^{11}$. Nustatyta, kad profesija susijusi su viešajame sektoriuje dirbančių specialistų motyvacija ir veiksniais (L. Bøgh Andersen, L. Holm Pedersen, 2012) ${ }^{12}$. Tačiau valstybès tarnybos vietų nèra tiek daug, kad jos galètų atitekti visiems tokị patị išsilavinimą ir profesiją turintiems specialistams, taip susidarant natūraliai konkurencijai ir lūkesčiui gauti darbą. Kadangi visuomenès sveikatos specialistais gali dirbti medicininį ar biomedicininį išsilavinimą turintys asmenys, darbo pasirinkimas pagal specialybę gali tapti vienu iš pagrindinių motyvų ir darbinantis savivaldybių visuomenès sveikatos biuruose. Lietuvoje buvo analizuota visuomenès sveikatos centruose dirbančių specialistų motyvacija, tačiau savivaldybių visuomenès sveikatos biuruose nebuvo atlikta panašių tyrimų.

Dauguma mokslininkų, analizuojančių organizacijas, sutinka, kad poreikiai, motyvai ir vertybès yra kintantys bręstant asmenybei bei per visą gyvenimo trukmę, taip pat ir pagal sukauptą darbo patirtị. Iki šiol prieštaringai mokslininkų vertinama tai, kaip kinta motyvacija ir motyvacinių veiksnių svarba skirtingame amžiuje. Pastebėta, kad saugumo ir priklausomybès poreikio stiprumas su amžiumi didejja, o savirealizacijos bei tobulejjimo mažèja (S. R. Rhodes, 1983) ${ }^{13}$.

Kitame tyrime iškelta ir patvirtinta hipotezè, kad amžius yra neigiamai susijęs su tobulëjimo motyvu, susijusiu su darbo funkcijomis ir rezultatais, kuriais siekiama pasiekti didesnị darbo našumą (S. R. Rhodes, 1983) ${ }^{13}$. Nesiekiant to-

9 Jankauskienè, V.; Kanapeckienè, V.; Narkauskaitè, L.; Valintèlienė, R. Visuomenès sveikatos priežiūros funkcijas vykdančių specialistų žinios ir igūdžiai. Visuomenès sveikata. 2012, 2(57): $45-56$.

10 Bright, L. Does Public Service Motivation Affect the Occupation Choices of Public Employees? Public Personnel Management. 2011, 40(1): 11-24.

11 Haase, H,; Lautenschläger, A. Career Choice Motivations of University Students. International Journal of Business Administration [interaktyvus]. 2011, 2(1) [žiūrèta 2013-04-18]. <http://www. sciedu.ca/journal/index.php/ijba/article/view/24>.

12 Bøgh Andersen, L. Holm Pedersen L. Public Service Motivation and Professionalism. International Journal of Public Administration. 2012, 35(1): 46-57.

13 Rhodes, S. R. Age-related differences in work attitudes and behavior: A review and conceptual analysis. Psychological Bulletin.1983, 93(2): 328-67. 
bulejjimo ir neužtikrinant tęstinio mokymosi, daroma prielaida, kad našumas ir galimi rezultatai gali nukentèti. Lyginant su jaunesniais darbuotojais, vyresniesiems mažiau buvo svarbūs motyvai, susiję su darbo prestižu ar materialiniu skatinimu. Tačiau dar visai neseniai atliktos metaanalizès atskleidè, kad nèra pastovių įrodymų, kad amžius neigiamai būtų susijęs su motyvacija ar pasiekimais darbe (T. W. H. Ng, D. C. Feldman, 2008) ${ }^{14}$.

Darbo stažas taip pat svarbus veiksnys analizuojant motyvacinius veiksnius. Darbo stažas ir amžius taip pat gali būti siejami tarpusavyje. Taip pat gali pasitaikyti stigmatizavimas, nukreiptas ił (M. Pitt-Catsouphes, Ch. Matz-Costa, J. James, 2012) ${ }^{15}$ :

Tiesiogines neigiamas išeitis. Jos pasižymi diskriminaciniais veiksmais ar elgesiu, kuris atspindi neigiamą nuostatą, nukreiptą $\mathfrak{x}$ kitus, pvz., vyresnius ar didesnị darbo stažą turinčius darbuotojus pamirštama ịvertinti ar paaukštinti, nes, pasak tyrimų autorių, amžiui didejjant išoriniai motyvaciniai veiksniai tampa ne tokie svarbūs.

Netiesiogines neigiamas išeitis. Nutinka, kad darbuotojai priima iš bendradarbių vyraujančias nuostatas, kad jis ar ji - per jauni. Taigi įtikima, kad asmuo „per jaunas“ ar „per senas“ tam, kad atliktų užduotị ar turètų atitinkamų kompetencijų. Tai taip pat gali būti stigmatizuojama ir dèl darbo stažo.

I amžių panašus veiksnys yra darbo stažas. Kartais darbo stažas grupuojamas $\mathfrak{i}$ lygius pagal išdirbtą laikotarpi ar atsižvelgiant ị darbo patirtị, sukauptas žinias, kompetencijas, igūdžius. Pastebima, kad jei darbuotojo karjeroje atsiranda pokyčiai ar nuo darbo atitrūkstama ilgesniam laikotarpiui (taip gali nutikti, pvz., dèl motinystės / tèvystès atostogų, ligos), vèl pradejjus darbą, darbo stažas priskiriamas pirmajam lygiui, taip lyg darbuotojas būtų ką tik pradejęs dirbti organizacijoje (M. Pitt-Catsouphes, Ch. Matz-Costa, E. Basen, 2009) ${ }^{16}$. Tiek amžius, tiek darbo stažas svarbūs organizuojant veiklą vietiniu lygmeniu, siekiant išvengti stigmatizavimo, kuris gali tapti demotyvuojančiu veiksniu.

Analizuojant motyvacinius veiksnius, politiniai aspektai taip pat svarbūs. Atsižvelgiant $i ̣$ tai, kiek respondentams svarbūs motyvai, galima skirtingai organizuoti veiklą, jei respondentams svarbiau tobulinimosi galimybès - organizuoti mokymus ar kvalifikacijos kèlimo kursus, jei respondentams svarbesnis materialus skatinimas, keisti apmokèjimo už darbą tvarką. Visuomenès sveikatos biurai yra valstybei priklausančios įstaigos, todèl finansinis skatinimas kaip išorinis motyvacinis veiksnys dažniausiai skiriamas už atitinkamą darbo laikotarpí, per kurị darbuotojas ịpareigotas vykdyti savo funkcijas. 2011 metais atliktoje

14 Ng, T. W. H.; Feldman, D. C. The relationship of age to ten dimensions of job performance. The Journal of applied psychology. 2008, 93(2): 39-423.

15 Pitt-Catsouphes, M., et. al. Through a Different Looking Glass: The Prism of Age. The Sloan Center on Aging \& Work, 2012.

16 Pitt-Catsouphes, M., et. al. Age \& generations: Understanding Experiences at the Workplace. The Sloan Center on Aging \& Work, 2009. 
sisteminejje apžvalgoje, ị kurią buvo ịtrauktos visos nuo 2008 metų iniciatyvos, susijusios su finansiniu skatinimu sveikatos sistemoje, nustatyta, kad atlygis už atitinkamą laiko periodą neefektyvus būdas siekiant darbo veiklos ar sistemos efektyvumo. Taip pat rekomenduojama kurti papilomas arba naujas finansavimo sistemas, kuriose būtų numatomas finansavimas pagal suteiktas paslaugas, pacientų ar populiacijos dydi ar tam tikro lygio paslaugas (G. Flodgren et al. $2011)^{17}$. Ne mažiau svarbu atsižvelgti ị tai, kaip darbuotojas vertina savo veiklą, laiko valdymą ar vadovo veiksmus darbuotojo atžvilgiu.

\section{Tyrimo metodologija}

Savivaldybių VSB asociacijos 2013 m. rugpjūčio mèn. duomenimis, iš Lietuvoje issteigtų 33 VSB, kurie aptarnavo ir kitas savivaldybes; VSB buvo patvirtinti 33 direktorių etatai, 130,5 visuomenès sveikatos specialistų etatai biuruose (iš tikrųjų dirbo 123 visuomenès sveikatos specialistai). Dèl mažos generalinès aibès, apklausoje buvo pakviesti dalyvauti visų biurų vadovai ir visuomenès sveikatos specialistai, be mokyklų visuomenès sveikatos specialistų (vykdyta tiksliné atranka). Iš 33 biurų vadovų apklausoje dalyvavo 12 (36,4 proc.), o iš 123 visuomenès sveikatos specialistų - 43 (35,0 proc.). Bendras tyrimo atsako dažnis 35,2 proc. Dažniausiai îvardinta darbo stažo trukmè buvo $5 \mathrm{~m}$. 1 lentelèje pateiktas tiriamųjų pasiskirstymas pagal pagrindinius demografinius ir socialinius veiksnius.

1 lentelè. Respondentų pasiskirstymas pagal pagrindines demografines ir socialines charakteristikas

\begin{tabular}{|l|c|c|}
\hline \multicolumn{1}{|c|}{ Požymis } & $\mathrm{n}$ & proc. \\
\hline Lytis & \multicolumn{2}{c|}{} \\
\hline Moteris & 50 & 90,9 \\
\hline Vyras & 5 & 9,1 \\
\hline Amžius & 30 & 57,7 \\
\hline iki 34 m. & 9 & 17,3 \\
\hline $35-44 \mathrm{~m}$. & 13 & 25 \\
\hline 45 m. ir daugiau & \multicolumn{2}{|c|}{} \\
\hline Specialybė & 29 & 52,7 \\
\hline Visuomenės sveikatos
\end{tabular}

17 Flodgren, G.; Eccles, M. P.; Shepperd, S.; Scott, A.; Parmelli, E.; Beyer, F. R. An overview of reviews evaluating the effectiveness of financial incentives in changing healthcare professional behaviours and patient outcomes. Cochrane Database of Systematic Review. 2011, 7. 


\begin{tabular}{|l|c|c|}
\hline Kita & 26 & 47,3 \\
\hline Pareigos & \multicolumn{2}{|l|}{} \\
\hline Vadovas & 12 & 21,8 \\
\hline V. s. stiprinimo specialistai & 17 & 30,9 \\
\hline V. s. stebėsenos specialistas & 13 & 23,6 \\
\hline $\begin{array}{l}\text { Vaikų ir jaunimo sveikatos } \\
\text { specialistai }\end{array}$ & 9 & 16,4 \\
\hline Kita (skiriasi įvardinimas) & 4 & 7,3 \\
\hline
\end{tabular}

Tyrimui atlikti ir reikalingiems duomenims surinkti buvo naudojama anoniminè anketa. Klausimyne naudotos kelios priemonés (2 lentelè) bei autorių sukurti klausimai, siekiant pritaikyti klausimyną visuomenès sveikatos specialistams. Toks klausimyno sudarymo metodas buvo pasirinktas, nes nebuvo rasta standartinių klausimynų, skirtų tirti visuomenès sveikatos specialistų darbui motyvuojančius veiksnius. Tyrimo anketą galima suskirstyti ị šias dalis: bendrieji klausimai, veiksniai, paskatinę dirbti visuomenès sveikatos biure, veiksniai (vertybès) svarbūs dirbant visuomenès sveikatos specialisto darbą, kuris atitinka darbą valstybės tarnyboje, motyvaciniai veiksniai darbui, subjektyvus psichologinès atmosferos vertinimas darbe. Kadangi naudotos tik klausimynų dalys, klausimų patikimumui nustatyti naudotas Cronbacho alfa koeficientas.

2 lentelè. Tyrime naudotų priemonių trumpas aprašymas

\begin{tabular}{|c|c|c|c|}
\hline Instrumentas & Šaltinis & Priemonès esmè & $\begin{array}{l}\text { Cronbacho } \\
\text { alfa }\end{array}$ \\
\hline $\begin{array}{l}\text { Darbo vertybių } \\
\text { klausimynas (WVQ) }\end{array}$ & $\begin{array}{l}\text { (Furnham, et al., } \\
1999)^{18}\end{array}$ & $\begin{array}{l}\text { Nustatyti vertybių svarbą } \\
\text { darbo kontekste }\end{array}$ & 0,7 \\
\hline $\begin{array}{l}\text { Motyvacija valstybès } \\
\text { tarnyboje }\end{array}$ & $\begin{array}{l}\text { (Perry, J. L., } \\
1996)^{19}\end{array}$ & $\begin{array}{l}\text { Nustatyti atsidavimą, } \\
\text { asmeninị pasiaukojimą }\end{array}$ & 0,54 \\
\hline $\begin{array}{l}\text { Psichologinio grupés } \\
\text { klimato skale }\end{array}$ & $\begin{array}{l}\text { (Puzinavičius, } \\
\text { B., 2005) }\end{array}$ & $\begin{array}{l}\text { Nustatyti subjektyviai } \\
\text { vertinamą psichologinę } \\
\text { aplinką remiantis } 12 \text { porų } \\
\text { požymiu }\end{array}$ & 0,94 \\
\hline
\end{tabular}

18 Furnham, A., et. al. Personality and Work Motivation. Personality and Individual Differences. 1999, (26): 1035-43.

19 Perry, J. L. Measuring Public Service Motivation: An Assessment of Construct Reliability and Validity. Journal of Public Administration Research and Theory. 1996, 6(1): 5-22.

20 Puzinavičius, B. Asmenybès ir grupés psichosocialine diagnostika. Anketu, klausimynu ir testu rinkinys. Vilnius: Generolo Jono Žemaičio Lietuvos karo akademija, 2005. 
Statistinèms hipotezėms tikrinti buvo taikyti Chi kvadrato ( $\chi 2)$, Pirsono (Pearson) tiesines koreliacijos koeficientas, kai skirstinys normalusis. Ranginiams, arba skaitmeniniams, duomenims, jei nenormalus skirstinys arba mažai stebejjimų, taikomas Spirmano koreliacijos koeficientas. Siekiant išsiaiškinti savivaldybių VSB darbuotojų motyvacinių veiksnių darbui ryši su amžiumi ir darbo stažu, skaičiuoti Spirmano koreliacijos koeficientai. Ryšiams tarp motyvacinių veiksnių ir išsilavinimo bei profesinių pareigų nustatyti buvo naudojamas Kruskal Wallis testas.

Respondentų buvo prašoma įvertinti, kiek svarbūs pateikti motyvaciniai veiksniai, susiję su vidinėmis ir išorinemis vertybėmis, dirbant VSB. Vertinimas atliktas pagal Likerto skalę, îvertinant 1-tu mažiausiai svarbius, o 5-tu - labiausiai svarbius. Vidinėms vertybėmis buvo priskirta: „noras igyti darbo patirties“, „asmeninio tikslo siekimas“, „prioritetas darbui su žmonėmis“, „greitas darbo rezultatas“, „,rūpinimasis kitų sveikata ir gerove“, „noras atlikti pilietinę pareigą“, „noras dalyvauti sveikatos politikos igyvendinime“, „geras pavyzdys“, „darbo turinys“. Išorinėms vertybėms buvo priskirta: „tobulinimosi galimybès“, „darbo užmokestis“, „karjeros galimybès“, „atsakomybès pobūdis“, „noras prisidèti prie visuomenès reikalų tvarkymo“, „socialinis statusas“, „organizacijos prestižas“, „pritarimas valdžios vykdomai politikai“, „,visuomenès vertinimas“

VSB darbuotojų veiklos ir situacijų, su kuriomis tenka susidurti dirbant, vertinimo rangų vidurkių palyginimas pagal vadovų ir darbuotojų grupes. Veiklos vertinimo skalëje vadovams klausimai šiek ties skyrèsi: „nekvalifikuotas mano vadovavimas", "mano, kaip vadovo atsako, apie atliktą darbą, nebuvimas", „mano, kaip vadovo ịsakymų, nuomonès nepastovumas“, „aš, kaip vadovas, visuomet tinkamai informuoju apie darbus, kuriuos reikia padaryti“, „aš, kaip vadovas, aiškiai išreiškiu, ko tikiuosi iš specialisto darbe“.

Buvo naudota visa Psichologinio grupès klimato skalè. Respondentų buvo prašoma įvertinti, kiek svarbūs pateikti motyvaciniai veiksniai, susiję su subjektyviai vertinama psichologine aplinka, būdinga dirbant VSB, pagal Likerto skalę, ìvertinant 1-tu mažiausiai būdinga, o 5-tu - labiausiai būdinga.

Bendroji subjektyviai vertinama motyvacija darbui buvo vertinama klausimu: „Kaip apskritai vertinate savo motyvaciją darbui?“ Kai galimi atsakymo variantai vertinti pagal Likerto skalę: 1 -„Labai silpna“, 2 - „Silpna“, 3 -„Neutrali“ 4 -„Stipri“, 5 -„Labai stipri“.

Visų respondentų amžius buvo sugrupuotas ị tris grupes: iki 34, 35-44, 45 m. ir vyresnių. Darbo stažas dirbant VSB negrupuotas, nes didžiausias darbo stažas nebuvo didesnis nei 8 metai.

\section{Tyrimo rezultatai}

Respondentų buvo prašoma nurodyti 5 svarbiausius motyvuojančius darbui veiksnius iš pateiktų klausimyne. Iš pateiktų atsakymų variantų respondentai 
dažniausiai pasirinko norą tobulèti ir savirealizaciją (1 pav.). Tarp svarbiausių motyvacinių veiksnių darbui respondentai ịvardino ir tai, kad jiems svarbu būti naudingiems visuomenei ir dirbti komandoje. Naudingumas visuomenei buvo aktualus 52,8 proc. respondentų. Penktuoju veiksniu tapo materialiniai veiksniai.

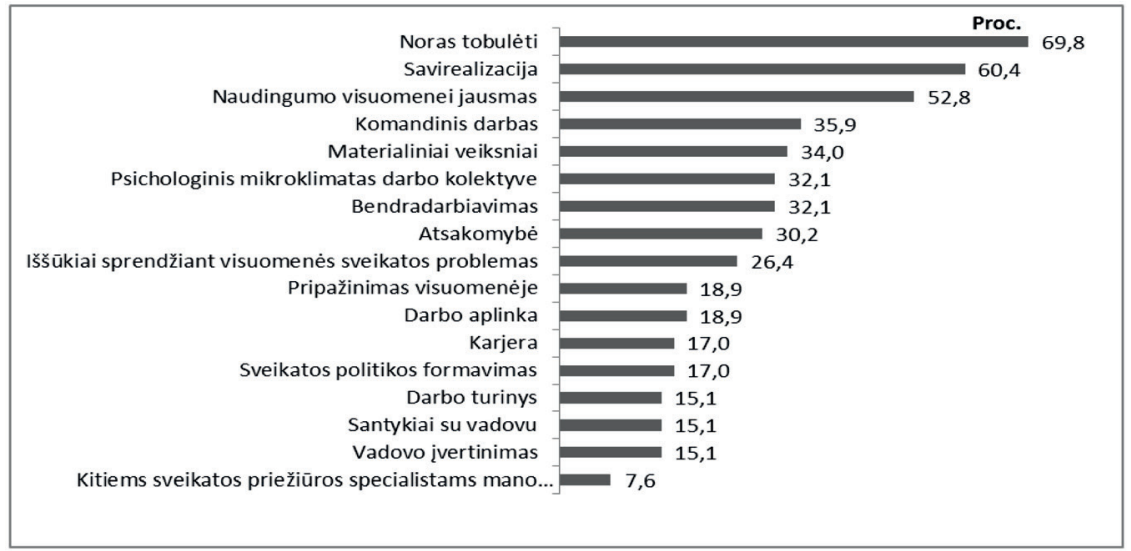

1 pav. Iš anketoje pateiktų motyvuojančių darbui veiksnių dažniausiai pasirinkti atsakymų variantai

VSB specialistų specialiųjų funkcinių užduočių analizė atskleidè, kad stebėsenai, sveikos gyvensenos skatinimui, vaikų ir jaunimo sveikatos stiprinimui vykdyti jie turi šiek tiek daugiau nei pagrindines žinias ir igūdžius (V. Jankauskienè ir kt., 2012.) ${ }^{21}$. Galbūt tai gali būti viena iš priežasčių, kodèl visiems specialistams pats svarbiausias motyvacinis veiksnys yra noras tobulèti. Tačiau noras tobulèti nebūtinai gali būti susijęs su žinių ar igūdžių trūkumu, tai taip pat gali būti siejama su nuolat kylančiais iššūkiais profesinejje veikloje, didejjančiu poreikiu prisitaikyti prie visuomenès vis naujų atsirandančių ar besikeičiančių problemų.

Specialybė. Keliama hipotezè, kad baigusiems visuomenès sveikatos studijas specialistams gali būti svarbesni motyvaciniai veiksniai, susiję su altruizmu, būdingu ir darbui valstybės tarnyboje. „Besirenkantys profesiją dažnai pirmenybę teikia dirbti viešajame sektoriuje. Igyta darbo patirtis valstybès tarnyboje gali būti traktuojama kaip tam tikras pretendento pranašumas." (J. Palidauskaité, $2008)^{22}$. Visuomenès sveikatos specialistais biuruose dirbę respondentai ịvardino

${ }_{21}$ Jankauskienė, V.; Kanapeckienė, V.; Narkauskaitè, L.; Valintelienė, R., supra note 9, 45-56.

22 Palidauskaitė, J. Valstybès tarnautojų motyvavimas: lyginamasis aspektas. Viešoji politika ir administravimas. 2008, 25: 7-18. 
baigę slaugos, visuomenės sveikatos ir visuomenès sveikatos vadybos, sveikatos edukologijos, biologijos, reabilitacijos, ergoterapijos, socialinio darbo medicinoje studijas. Vadovai dažniausiai ịvardino baigę visuomenès sveikatos, slaugos ir reabilitacijos studijas, tik keletas buvo baigę su administravimu susijusias studijas. Lyginant, ar tyrime dalyvavę ir skirtingą išsilavinimą turintys specialistai ir vadovai motyvacinius veiksnius vertina skirtingai, tokie skirtumai nenustatyti. Palyginus motyvacinių veiksnių skalių vertinimo rangų vidurkius pagal specialybę (visuomenès sveikatos ar kita), statistiškai reikšmingi skirtumai nebuvo nustatyti nè vienoje išsilavinimo grupeje, lyginant su pasiaukojimo, vidinių ir išorinių vertybių bei veiklos teiginiais. I tai turètų būti atsižvelgiant vykdant darbuotojų atranką.

Altruizmas. Renkantis specialybę, galvojama ir apie tai, kokia bus profesinè veikla (H. Haase, A. Lautenschläger, 2011) ${ }^{23}$. Pasiaukojimas taip pat svarbus veiksnys, kurio suvokimas parodo, kaip stipriai asmuo vertina savo pastangas ar altruizmą. Pagal J. L. Perry MVT klausimyną, tai galima vertinti kaip išreiškiamą patriotiškumą, pareigos jausmą visuomenei kaip altruistinę išraišką. Visiškam altruizmui būdinga tai, kad tam tikrą darbą žmogus gali atlikti be atlygio ir gerai jaustis. Pusè respondentų sutiko arba iš dalies sutiko su teiginiu: „darbas vardan visuomenès sveikatos leidžia man gerai jaustis, net jei už tai negaunu atlygio“ (50,9 proc.), penktadalis nesutiko arba iš dalies nesutiko su šiuo teiginiu (20 proc.). Atlygis nebūtinai turi būti materialus. Viena iš alternatyvų yra atgalinis ryšys, visuomenès ịvertinimas. Net 89 proc. respondentų iš dalies sutiko arba sutiko su teiginiu, kad „net negaunant iš visuomenès teigiamo grižtamojo ryšio, aš vis tiek dèsiu visas pastangas, kad padéčiau“. Kaip kraštutinè altruizmo forma (naudinga visuomenei, bet žalinga asmeniui) - pasirinktas asmeninis pasiaukojimas. Su teiginiu „aš esu iš tų nedaugelio žmonių, kurie rizikuos prarasti kažką asmeniško, tam, kad padètų kitiems" sutiko arba iš dalies sutiko 50,0 proc. respondentų.

Vidinių ir išorinių vertybių svarba. 3 lenteleje pateiktos išorinių vertybių sąsajos su amžiumi ir darbo stažu. Vertinant vidinių vertybių teiginių su amžiumi ir darbo stažu sąsajas, nustatyta labai silpna koreliacija tarp amžiaus ir prioriteto darbui su žmonèmis $(0,298, p=0,03)$ bei vidutine, tačiau neigiama amžiaus koreliacija su noru igyti darbo patirties $(-0,44, \mathrm{p}=0,002)$. Nenustatyta né viena statistiškai reikšminga koreliacija tarp darbo stažo ir vidinių vertybių skalės teiginių.

23 Haase, H,; Lautenschläger, A., supra note 11. 
3 lentelè. Išorinių vertybių sąsajos su amžiumi ir darbo stažu

\begin{tabular}{|c|c|c|c|c|c|}
\hline \multirow[b]{2}{*}{ Grupè } & \multirow[b]{2}{*}{ Teiginiai } & \multicolumn{2}{|c|}{ Amžius } & \multicolumn{2}{|c|}{ Darbo stažas } \\
\hline & & $\begin{array}{l}\text { Spirmano } \\
\text { kor. koef. }\end{array}$ & $\mathrm{p}$ & $\begin{array}{l}\text { Spirmano } \\
\text { kor. koef. }\end{array}$ & $\mathrm{p}$ \\
\hline \multirow{9}{*}{ 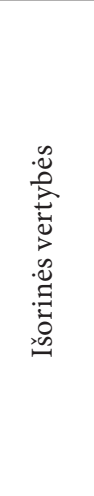 } & Tobulinimosi galimybės & $-0,221$ & 0,123 & $-0,269$ & 0,057 \\
\hline & Darbo užmokestis & 0,021 & 0,885 & $-0,094$ & 0,507 \\
\hline & Karjeros galimybès & $-0,486$ & 0,000 & $-0,146$ & 0,305 \\
\hline & Atsakomybės pobūdis & $-0,003$ & 0,985 & 0,057 & 0,686 \\
\hline & $\begin{array}{l}\text { Noras prisidèti prie visuomenès } \\
\text { reikalų tvarkymo }\end{array}$ & 0,055 & 0,707 & $-0,218$ & 0,125 \\
\hline & Socialinis statusas & $-0,074$ & 0,608 & $-0,039$ & 0,786 \\
\hline & Organizacijos prestižas & 0,330 & 0,018 & 0,286 & 0,04 \\
\hline & $\begin{array}{l}\text { Pritarimas valdžios vykdomai } \\
\text { politikai }\end{array}$ & $-0,020$ & 0,893 & $-0,003$ & 0,983 \\
\hline & Visuomenès vertinimas & 0,038 & 0,794 & 0,024 & 0,864 \\
\hline
\end{tabular}

Amžius. Kai kurie mokslininkai teigia, kad amžius svarbus motyvacinis veiksnys darbui (S. R. Rhodes, $1983^{24}$; K. S. Shultz ir G. A. Adams, 2012 25 ; D. T. A.

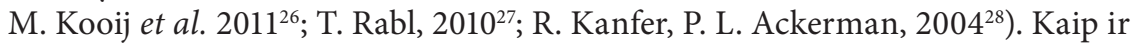
kitų autorių tyrimuose, taip ir šiame rezultatai parodè, kad dalies išorinių motyvų svarba su amžiumi mažejo. Gauti duomenys parodè, amžius yra neigiamai susijęs su noru igyti darbo patirties, karjeros galimybių. Nors amžius neigiamai susijęs su socialinio statuso svarba, pritarimu valdžios vykdomai politikai, gauti ryšiai yra labai silpni ir statistiškai nereikšmingi. Taigi nors su amžiui tobulèjimas ir karjeros galimybès nèra tokios svarbios, darbas su žmonėmis tampa vis svarbesnis. Tai patvirtina ir kitoje klausimų grupeje rastas teiginio „Aš esu iš tų nedaugelio žmonių, kurie rizikuos prarasti kažką asmeniško tam, kad padètų kitiems" ir amžiaus ryšys. Šis teiginys rodo, kad pagalba kitiems, vidinės vertybės gali tapti svarbesni nei asmeniniai dalykai. Nenustatytas ryšys tarp amžiaus ir visuomenès vertinimo parodo, kad su amžiumi gali stiprèti altruizmo išraiška. Tačiau tai dar nepaneigia, kad vyresnio amžiaus darbuotojams nèra poreikio būti ịvertintiems.

\footnotetext{
24 Rhodes, S. R., supra note 13, 328-367.

25 Shultz, K. S.; Adams, G. A. Aging and Work in the 21st Century. Psychology Press, 2012, 370.

26 Kooij, D. T. A. M., et. al. Age and work-related motives: Results of a meta-analysis. Journal of Organizational Behavior. 2011, 32(2): 197225.

27 Rabl, T. Age, discrimination, and achievement motives: A study of German employees. Personnel Review. 2010, 39(4): 448-467.

28 Kanfer, R.; Ackerman, P. L. Aging, Adult Development, and Work Motivation. The Academy of Management Review. 2004, 29(3): 440.
} 
Nustatytas vidutinio stiprumo neigiamas koreliacinis ryšys tarp karjeros galimybių svarbos respondentams ir amžiaus $(-0,486, p=0,000)$. Taip pat nustatytos silpnos koreliacijos tarp organizacijos prestižo ir amžiaus $(0,330, p=0,02)$ bei darbo stažo $(0,286, p=0,04)$. Nenustatyta jokia kita statistiškai reikšminga koreliacija tarp darbo stažo / amžiaus su tobulinimosi galimybėmis, darbo užmokesčiu, atsakomybės pobūdžiu, noru prisidèti prie visuomenès reikalų tvarkymo, pritarimo valdžios politikai ar visuomenès vertinimo. Organizacijos prestižas gali būti siejamas su karjera, subjektyviai vertinamais pasiekimais, skirtingomis funkcijomis ir atliekama veikla.

Veikla. Analizuojant veiklas ir situacijas, su kuriomis tenka susidurti dirbant VSB, sąsajas su amžiumi ir darbo stažu, nustatyta silpna amžiaus ir teiginio „mano darbo veikla aiškiai apibrèžta" neigiama koreliacija $(-0,298, p=0,03)$, kaip ir amžiaus su nuolatinès ittampos dèl didelio krūvio $(0,288, \mathrm{p}=0,04)$. Darbo stažas silpnai koreliuoja su teisinimusi dèl atliktų darbų, nuomone, kad atliekamos užduotys atrodo bereikšmès ir nereikalingos $(0,309, p=0,024)$. Tai gali būti ir dèl to, kad veikla nèra aiškiai apibrèžta, suprantama bei pagrịstas jos būtinumas. Nustatytas neigiamas ryšys tarp darbo stažo ir darbo veiklos aiškaus apibrèžtumo tai patvirtina. Tai pagrịstų kitų tyrimų autorių iškeltą hipotezę, kad persikvalifikavusiems ar iš karto po studijų pradejusiems dirbti specialistams darbo stažas prilygsta pradiniam arba gali būti stigmatizuojamas (M. Pitt-Catsouphes et al. 201229; M. Pitt-Catsouphes et al. 200930). Net jei ir tikimasi, kad darbo stažui didejant darbuotojas pats supras ar ieškos darbo veiklos prasmès, vadovams rekomenduojama ị tai papildomai atsižvelgti. Šiek tiek stipresnè tačiau vis dèlto silpna koreliacija tarp darbo stažo ir teiginio "nekvalifikuotas vadovavimas“ $(0,349, \mathrm{p}=0,01)$. Kaip ir su amžiumi, taip pat nustatyta koreliacija tarp darbo stažo ir ịtampos, patiriamos dèl didelio krūvio $(0,503, p=0,000)$. VSB funkcijos ir veikla reglamentuota, dažnai planuojama i priekį, todèl veiklos pokyčiai ar darbo krūvis mažai kintantys. Suprantama, kad jei veikla nèra aiškiai apibrèžta, tai gali reikalauti papildomų pastangų bei sukelti ịtampą atliekant užduotis. Ar respondentų amžiui didejjant darbo krūvis sukelia ịtampą dẻl prastejjančio prisitaikymo, ar dèl didesnès darbo patirties, susijusios su amžiumi, daugejančių darbo užduočių, reikia tolesnių tyrimų. Neigiamai silpnai koreliuoja darbo stažas su darbo veiklos aiškiu apibrèžtumu $(-0,293, \mathrm{p}=0,032)$. Darbo krūvis ir veikla darbdavio ir specialistų gali būti suvokiami skirtingai. Jei veikla siejama su rezultatais, tai gali būti ir vaidmens konfliktas - veiksnys, atsirandantis neatitinkant darbuotojo įsitikinimams dèl to, ko iš jo tikimasi, ir ko tikisi jis pats.

Psichologinis grupés klimatas. Komandinis darbas, psichologinis mikroklimatas darbo kolektyve yra tarp pirmų šešių svarbiausių motyvacinių veiksnių

29 Pitt-Catsouphes, M., et. al., supra note 15.

30 Pitt-Catsouphes, M., et. al. supra note 16. 
darbui pasirenkant iš sąraše pateiktų veiksnių. Respondentų taip pat buvo klausiama, kokios savybès būdingos jiems dirbant VSB. Kuo buvo didesnis įvertis, tuo stipriau pasireiške savybè. Pagal psichologinio grupès klimato sąsajos su amžiumi ir darbo stažu nustatyta koreliacija tarp bendrosios motyvacijos ir pasitenkinimo jausmo $(0,41, \mathrm{p}=0,003)$, kūrybiškumo $(0,35, \mathrm{p}=0,01)$, optimizmo $(0,29, \mathrm{p}=0,04)$ ir partnerystės $(0,42, \mathrm{p}=0,00)$. Tarp motyvacinių veiksnių darbui svarbos ir dvasingumo nustatyta silpna, tačiau statistiškai reikšminga koreliacija $(0,29, \mathrm{p}=0,04)$.

Pareigos ir išsilavinimas. Veiklos vertinimo skalių rangų vidurkių palyginimas rodo, kad vadovai statistiškai reikšmingai dažniau susidurdavo su situacijomis, kai „darbe norint pasiekti tikslus reikia ịdèti daug pastangų“ $(p=0,02)$, taip pat su situacijomis, kai „darbas kupinas iššūkių“ ( $\mathrm{p}=0,04)$, ir supratimu: „žinau, kad mano darbas labai svarbus" ( $\mathrm{p}=0,03)$. Rangų vidurkis taip pat statistiškai reikšmingai išsiskyrè analizuojant vadovų ir darbuotojų nuomonę apie nuolatinès ịtampos, dèl didelio krūvio pasireiškimą $(\mathrm{p}=0,01)$. Prieš metus atliktame VSB veiklos ir veiklos efektyvumo vertinime pastebima, kad per dideli darbo krūvị turintys nurode 31,7 proc. respondentų (J. Klimavičiūtè, 2013) ) $^{31}$. Šiame tyrime 25,9 proc. respondentų ịvertinę savo veiklą visuomenès sveikatos biure sakè jaučiantys nuolatinès įtampos dèl didelio krūvio pasireiškimą „dažniausiai“ arba „visada“. Nebuvo nustatyti statistiškai reikšmingi skirtumai tarp išsilavinimo rangų vidurkių ir pasiaukojimo, vidinių ir išorinių vertybių teiginių ar kitų motyvacinių veiksnių grupių.

Respondentų subjektyviai ịvertinta bendroji motyvacija. Iš viso bendrąją motyvaciją subjektyviai vertino 52 respondentai, iš jų 11 (21,15 proc.) vadovų ir 41 (78,84 proc.) specialistas. Lyginant vadovus su specialistais, statistiškai reikšmingų skirtumų vertinant subjektyvią bendrąją motyvaciją nenustatyta (4 lentelè).

4 lentelè. Subjektyviai vertinamos bendrosios motyvacijos pasiskirstymas

\begin{tabular}{|l|c|c|c|cc|c|c|}
\hline \multirow{2}{*}{$\begin{array}{c}\text { Subjektyviai vertinama } \\
\text { bendroji motyvacija }\end{array}$} & \multicolumn{2}{c|}{$\begin{array}{c}\text { Visų } \\
\text { respondentuc }\end{array}$} & \multicolumn{2}{c|}{ Vadovu } & \multicolumn{2}{c|}{ Specialistų } \\
\cline { 2 - 8 } & $\mathrm{n}$ & proc. & $\mathrm{n}$ & proc. & $\mathrm{n}$ & proc. \\
\hline L. silpna ar silpna & 2 & 3,8 & 0 & 0,0 & 2 & 4,9 \\
\hline Neutrali & 12 & 23,1 & 3 & 27,3 & 9 & 22,0 \\
\hline L. stipri ar stipri & 38 & 73,1 & 8 & 72,7 & 30 & 73,2 \\
\hline Iš viso & 52 & 100 & 11 & 100 & 41 & 100 \\
\hline
\end{tabular}

31 Klimavičiūtè, J., supra note 3. 
Nustatytas neigiamas silpnas koreliacinis ryšys tarp bendrojo motyvacijos vertinimo ir amžiaus $(-0,21, \mathrm{p}=0,04)$, darbo stažo $(-0,26 ; \mathrm{p}=0,01)$, darbuotojo nuomonès dèl nekvalifikuoto vadovavimo $(-0,25, \mathrm{p}=0,01)$, vadovų nuomonès nepastovumo $(-0,21, \mathrm{p}=0,03)$. Nustatytas teigiamas silpnas koreliacinis ryšys tarp subjektyviai vertinamos bendrosios motyvacijos ir prioriteto darbui su žmonėmis $(0,36, p=0,00)$, siekimo rūpintis kitų sveikata ir jų gerove $(0,27$, $\mathrm{p}=0,01)$, noras dalyvauti sveikatos politikos igyvendinime $(0,45, \mathrm{p}=0,00)$, gero pavyzdžio turejjimas $(0,24, \mathrm{p}=0,01)$, noras prisidèti prie visuomenès reikalu tvarkymo $(0,24, \mathrm{p}=0,01)$ ir esant didesniam pritarimui valdžios politikai $(0,28$, $\mathrm{p}<0,00)$.

\section{Tyrimo ribotumas}

Dèl mažo atsako dažnio tyrimo rezultatai atspindi tik tyrime dalyvavusiųjų nuomonę. Nors tyrimo anketas buvo prašoma užpildyti visų Lietuvos savivaldybių VSB vadovų ir visuomenès sveikatos specialistų, dirbančių biuruose, tarp atsisakymų dalyvauti priežasčių buvo ịvardinama baimė, kad vadovas gali išsiaiškinti, kokie yra darbuotojo motyvaciniai veiksniai darbui. Dèl atsakymo trumpumo sunku suprasti, ar tai dèl baimès vadovui, ar dèl asmeninio neigiamo savo motyvacijos vertinimo. Todèl neatmetama prielaida, kad atsakiusieji galèjo būti tie specialistai ir vadovai, kurie ịstaigoje savo motyvacinius veiksnius vertina geriau, kaip ir bendrąją motyvaciją. Tyrime nebuvo tiriamas polinkis stengtis darbe, kur nustatoma, koks elgesys darbuotojui gali būti būdingas pagal pareigas, nuo pareigų nepriklausantis elgesys, neveiklumas darbe, nusišalinimas nuo darbo ar ketinimas išeiti, kas leistų šiuos dalykus sieti su motyvaciniais veiksniai ir motyvacija. Taip pat motyvaciniai veiksniai nebuvo siejami su asmenybės bruožais.

\section{Išvados}

Tyrime dalyvavusių savivaldybių visuomenès sveikatos biurų vadovų ir visuomenès sveikatos specialistų nuomone, motyvacinių veiksnių svarba labiausiai išsiskyrè vertinant amžių ir pareigas. Karjeros galimybės, kaip išorinė vertybè, amžiui didejjant tampa mažiau svarbios $(-0,486, p=0,000)$.

Nustatytas ryšys tarp amžiaus ir prioriteto darbui su žmonèmis, noro igyti darbo patirties, nuolatinès ịtampos dèl didelio krūvio. Pagal pareigas analizuojant motyvacinius veiksnius, labiausiai išsiskyrė veiksniai, susiję su veikla. Vadovai, lyginant su specialistais, statistiškai reikšmingai dažniau ịvardino patiriantys nuolatinę ịtampą dèl didelio krūvio. Vadovai reikšmingai dažniau nei specialistai įvardino susiduriantys su iššūkiais ir, kad norint pasiekti tikslus, reikia įdèti daugiau pastangų. Daugiau nei $2 / 3$ respondentų bendrąją motyvaciją jivertino kaip „stiprią ar labai stiprią“. 
Tarp bendrosios motyvacijos nustatytas ryšys su amžiumi, darbo stažu, prioritetu darbui su žmonemis, noru dalyvauti sveikatos politikos igyvendinime, kas ir yra viena iš svarbiausių veiklos krypčių VSB.

\section{Pasiūlymai}

\section{Vadovams:}

Tyrime dalyvavusieji specialistai ir darbuotojai ịvardino dažnai jaučiantys įtampą dèl didelio darbo krūvio bei tai, kad susiduria su problema, kad dalis dienos darbų būna neplanuoti. Todèl rekomenduojama ugdyti darbo veiklos ir laiko planavimo ir valdymo igūdžius. Darbuotojui planuojant savo veiklą, didèja jo paties asmeninè atsakomybè, užuot ją prièmus kaip užduotị, kurią jis tiesiog privalo padaryti.

Psichologiné darbo aplinka tyrime dalyvavusiems VSB darbuotojams yra itin svarbi, todèl labiau tiktų kolektyviniai apdovanojimai, susiję su grupès veikla. Individualūs apdovanojimai gali paskatinti konkurenciją ir slopinti partnerystę, kuri buvo susijusi su bendrosios motyvacijos vertinimu. Darbas komandoje buvo vienas iš svarbiausių motyvacinių veiksnių, todèl, kai įmanoma, visuomenès sveikatos biurų vadovams skirstyti darbus komandoms. Daugelyje biurų dirba tik po vieną atitinkamos srities specialistą, todèl rekomenduojama skirti papildomas lěšas darbo vietų sukūrimui.

\section{Politiniai-ekonominiai:}

Tyrime nustatyta, kad materialus atlygis respondentams taip pat vienas iš svarbiausių motyvacinių veiksnių darbui, tačiau atlygis už išdirbtą laiką nèra efektyvi priemonè skatinant darbinę veiklą. Todèl reikètų tobulinti materialinio skatinimo sistemą pagal kvalifikacijos lygị, darbo stažą, produktyvumą, papildomas darbo užduotis.

\section{Literatūra}

1. Bøgh Andersen, L.; Holm Pedersen, L. Public Service Motivation and Professionalism. International Journal of Public Administration. 2012, 35(1): 46-57.

2. Bright, L. Does Public Service Motivation Affect the Occupation Choices of Public Employees? Public Personnel Management. 2011, 40(1): 11-24.

3. Diskienè, D. Darbo motyvacija viešajame sektoriuje: iššūkiai ir tikrovè. Viešasis sektorius ir socialine raida. Naujausios tendencijos. 2008, 4(20).

4. Grybienè, A.; Šimbelis, D. Pokyčiai organizacijoje: pasipriešinimo pokyčiams valdymas. KTU Panevěžio institutas, 2005, p. 68-71.

5. Flodgren, G.; Eccles, M. P.; Shepperd, S.; Scott, A.; Parmelli, E.; Beyer, F. R. An overview of reviews evaluating the effectiveness of financial incentives in changing healthcare professional behaviours and patient outcomes. Cochrane Database of Systematic Reviews. 2011, 7. 
6. Furnham, A., et. al. Personality and work motivation. Personality and Individual Differences. 1999, 26: 1035-43.

7. Haase, H.; Lautenschläger, A. Career Choice Motivations of University Students. International Journal of Business Administration [interaktyvus]. 2011, 2(1) [žiūrèta 2013-04-18]. <http://www.sciedu.ca/journal/index.php/ijba/article/view/24>.

8. Jankauskienè, V. et. al. Visuomenès sveikatos priežiūros funkcijas vykdančių specialistų žinios ir ịgūdžiai. Visuomenès sveikata. 2012, 2(57): 45-56.

9. Jovaiša, L. Enciklopedinis edukologijos žodynas. Vilnius: Gimtasis žodis. 2007.

10. Kanfer, R.; Ackerman, P. L. Aging, Adult Development, and Work Motivation. The Academy of Management Review. 2004, 29(3): 440.

11. Kim, S.; Vandenabeele, W. Measuring Public Service Motivation: Developing an Instrument for International Use. The annual conference of the European Group for Public Administration (Toulouse, France, 8-10 September, 2010). Toulouse.

12. Klimavičiūte, J. Visuomenès sveikatos biurų veiklos ir veiklos efektyvumo vertinimas: magistro diplominis darbas. Kaunas: Lietuvos sveikatos mokslų universitetas; 2013.

13. Kooij, D. T. A. M., et. al. Age and work-related motives: Results of a meta-analysis. Journal of Organizational Behavior. 2011, 32(2): 197-225.

14. Lietuvos Respublikos Konstitucinio Teismo 2004 m. gruodžio 13 d. nutarimas „Dèl kai kurių teisės aktų, kuriais reguliuojami valstybės tarnybos ir su ja susiję santykiai, atitikties Lietuvos Respublikos Konstitucijai ir įstatymams“. Valstybès žinios. 2004, Nr. 181-6708. 21.

15. Pitt-Catsouphes, M., et. al. Age \& generations: Understanding Experiences at the Workplace. The Sloan Center on Aging \& Work, 2009.

16. Pitt-Catsouphes, M., et. al. Through a Different Looking Glass: The Prism of Age. The Sloan Center on Aging \& Work, 2012.

17. Palidauskaité, J. Valstybės tarnautojų motyvavimas: lyginamasis aspektas. Viešoji politika ir administravimas. 2008, 25: 7-18.

18. Perry, J. L.; Hondeghem, A. Building Theory and Empirical Evidence about Public Service Motivation. International Public Management Journal. 2008,11(1): 3-12.

19. Perry, J. L. Measuring Public Service Motivation: An Assessment of Construct Reliability and Validity. Journal of Public Administration Research and Theory. 1996, 6(1): 5-22.

20. Perry, J. L.; Wise, L. R. The Motivational Bases of Public Service. Public Administration Review. 1990, 50(3): 367.

21. Puzinavičius, B. Asmenybès ir grupès psichosocialinè diagnostika. Anketų, klausimynų ir testų rinkinys. Vilnius: Generolo Jono Žemaičio Lietuvos karo akademija, 2005.

22. Rabl, T. Age, discrimination, and achievement motives: A study of German employees. Personnel Review. 2010, 39(4): 448-67.

23. Rhodes, S. R. Age-related differences in work attitudes and behavior: A review and conceptual analysis. Psychological Bulletin.1983, 93(2): 328-67.

24. Šavareikienè, D. Motyvacija vadybos procese: mokomoji knyga. Šiauliai, 2008.

25. Shultz, K. S.; Adams, G. A. Aging and Work in the 21st Century. Psychology Press. 2012,370 . 


\title{
Motivational Factors of Work of the Public Health Bureaus Specialists
}

\author{
Ingrida Jaselskytė, Skirmantė Sauliūnè \\ Lithuanian University of Health Sciences, Lithuania
}

Summary. Aim of the study. The study seeks to identify motivational factors for work of public health specialists of public health bureaus of municipality.

Methods. The questionnaire was filled by 55 public health specialists and managers working at the public health bureaus of municipality, excluding public health specialists working at schools. The response rate was $35.2 \%$. Data analysis was performed using the following criteria: chi-square ( $\chi 2)$, the linear Pearson and Spearman's rank correlation coefficient and Kruskal Wallis test. Cronbach alpha was used to estimate the test reliability.

Results. Wish to help, feedback from the public and the psychological atmosphere at work are factors which were important for managers as well as for specialists. The importance of motivational factors was mostly dependent of age in assessing responsibilities and activity related to work. Career opportunities, as an external value, becomes less important with increasing age $(-0.486, p=0.000)$. A positive correlation was observed between age and priority to work with people, constant stress due to workload and negative correlation between ages and wish to gain work experience. According to the analysis of motivational factors compared by the position, most factors had a difference in the activity group. The study showed that statistically significant difference exists in comparing managers and specialists working under constant stress due to workload $(p=0.01)$. Managers were significantly more likely to face challenges than specialists $(p=0.04)$ and stated that in order to achieve goals, more effort is needed compared to specialists $(p=0.02)$. More than two-thirds of the respondents rated their general motivation as "strong or very strong". Statistically significant difference was found in assessing the general motivation by age $(-0.21, p=0.04)$, duration of employment $(-0.26$, $p=0.01)$, priority to work with people $(0.36, p<0.000)$, willingness to participate in health policy implementation $(0.45, p<0.000)$, which is one of the most important activities of the $\mathrm{PHB}$.

Conclusions. The importance of motivational factors of managers and specialists were different depending on age, length of service and position. The findings indicated that the general motivation of PHB specialists and managers was related to age, years of service, priority to work with people, desire to participate in the implementation of health policy.

Keywords: public health bureaus, public health specialists, motivational factors of work, motivation, public service. 
Ingrida Jaselskyte், Lietuvos sveikatos mokslų universiteto Sveikatos tyrimų institutas, visuomenès sveikatos magistrè. Mokslinių tyrimų kryptys: visuomenès sveikatos politika, alkoholio kontrolès politika, gyvensenos keitimo intervencijos, elektroninè sveikata.

Ingrida Jaselskyte், Lithuanian University of Health Sciences, Health Research Institute, Master in Public Health. Research interests: public health policy, alcohol control policy, behavior interventions, electronic health.

Skirmantė Sauliūnè, Lietuvos sveikatos mokslų universiteto Sveikatos vadybos katedros profesorè. Mokslinių tyrimų kryptys: sveikatos priežiūros valdymas ir organizavimas, sveikatos netolygumai.

Skirmantė Sauliūnè, Lithuanian University of Health Sciences, Department of Health Management, Professor. Research interests: health care management and organization, health inequalities. 